\title{
The impact of burning on the structure and mineral composition of bat guano
}

\author{
Joyce Lundberg (10 ${ }^{1 *}$ and Donald A. McFarlane (1D ${ }^{2}$ \\ ${ }^{1}$ Department of Geography and Environmental Studies, Carleton University, Ottawa, K1S 5B6, Canada \\ ${ }^{2}$ Keck Science Department, The Claremont Colleges, California, USA
}

\begin{abstract}
Here we addressed the question of whether burning of guano produces a characteristic suite of morphological changes and/or unique mineralogical products. The changes observed in our experimental burning of guano (both fresh and decayed) included colour change (blackening), grain size and morphological change (grain size generally reduced, morphology rendered generally less distinct), alteration of minerals by dehydration (e.g., gypsum to anhydrite, brushite to whitlockite), and production of new minerals or compounds (e.g., augelite, bayerite, giniite, graphite, oldhamite, strontium apatite, tridymite). The key morphological feature we found that may be diagnostic of burning was severe damage to crystals from rapid dehydration (cracks and striations, leading to eventual fragmentation). The key mineralogical feature we found was production of graphite. The high temperature exotic minerals that were produced (giniite, augelite, tridymite, oldhamite) were all found not to be high temperature obligate. Evidence gleaned from the literature suggests that a great number of the minerals associated with high temperatures can also be synthesized in low temperature settings such as weathering or microbial action (exemplified in the extremely complex biology and biochemistry of decaying guano). While the presence of any one of these minerals is not diagnostic of fire, it could be argued that the suite taken as a whole is moderately strong evidence for burning. In future studies, the chemistry of carbon aromaticity may prove to be the best diagnostic test for pyrolysis. A survey of the conditions under which documented spontaneous ignition occurs leads us to conclude that spontaneous ignition of guano inside a cave is an extremely unlikely event, and any suggestion/assertion to this effect should be rigorously supported.
\end{abstract}

Keywords: insectivorous bat guano, combustion, gypsum, anhydrite, graphite

Received 14 March 2021; Revised 4 May 2021; Accepted 10 May 2021

Citation: Lundberg, J., McFarlane, D.A., 2021. The impact of burning on the structure and mineral composition of bat guano. International Journal of Speleology, 50(2), 189-202.

https://doi.org/10.5038/1827-806X.50.2.2387

\section{BACKGROUND}

Although a relatively rare event, a few reports have been published in recent years mentioning burning of guano in caves. Oakley (1954), discussing burnt material in a South African cave, suggested that a human-created hearth set fire to underlying dry guano. Berna et al. (2012), from a similar situation in South Africa, demonstrate that the burnt remnants were of plants and bone rather than of guano. Martini (1994a, b, 1997) reports a "white, porous, and friable slag" from a cave in Namibia, probably from guano combustion, but with no indication if the fire was natural or anthropogenic. Urbani (1996) reports evidence of burned guano from two caves in Venezuela, but, again, with no indication of the initial cause of the fires (although, given that the date of commencement is known, this implies a human origin). One of the very few examples of a fire in a cave that might clearly be attributed to natural causes is lightning strike in cave entrances (Brain, 1967). While theoretically logical, and lightning is known to be attracted to the moist, conductive air of some cave entrances (Halliday, 1954), we could find no certified examples in the literature (e.g., anecdote suggests that lightning may have started a guano fire in a cave entrance near Blowout, Texas; however, another anecdote suggests that this fire was triggered by a thrown torch: San Antonio News, 2019). Perhaps the best known "guano" cave fire was the catastrophic destruction of Pleistocene ground sloth dung in Rampart Cave, Arizona, which burned for 9 months after being ignited by persons unknown in 1976 (Schmidt et al., 1992). Notably, the deposit, which was $1.5 \mathrm{~m}$ deep, overlying ancient bat guano, had survived $\sim 30,000$ years of active accumulation 
and 11,000 years of preservation (Long et al., 1974) without spontaneous combustion.

In spite of the subsequent copious references to this site in the literature (which falsely imply that natural fires in caves are common) there is apparently only one location where burned guano is asserted, with a reasonable evidence base, to have naturally spontaneously ignited - the Cioclovina Cave in Romania. The studies on the subject (Onac et al., 2002: Onac \& White 2003; Onac \& Effenberger, 2007; Onac et al., 2007) forward the suggestion (in the later publications changing more towards assertion than suggestion) that spontaneous ignition is the explanation for the guano fire - that "owing to microbial processes, the temperature inside the buried guano increased until spontaneous ignition led to its combustion" (Onac et al., 2006, 2007). While the evidence for spontaneous ignition is weak (perhaps indicated more by the absence of evidence for an anthropogenic cause), the evidence for guano having combusted is stronger. The key is the finding of the mineral berlinite - normally a high temperature mineral produced by the dehydration of variscite, taranakite and/or brushite - and, more recently (Onac et al., 2006), another typically hightemperature mineral - hydroxyellestadite - offering further indication that guano combustion might be a reasonable explanation for the suite of minerals found in this particular situation (although it must be noted that attempts to replicate these results, from the same sites, by Marincea and Dumitraş, 2005, failed to find these minerals). As ancillary (but somewhat vague) evidence of fire, Onac and White (2003) report finding charred material "in the vicinity".

Another report of berlinite in a cave sediment is from decaying guano in Niah Great Cave, Borneo (McFarlane \& Lundberg, 2018). Here, however, there is no evidence whatsoever for fire. McFarlane and Lundberg (2018) were the first to offer an alternative hypothesis for the presence of berlinite: rather than fire, it might instead have resulted from microbial biochemical alteration of variscite. In a slightly circular argument, some publications assume that burning must have occurred in order to explain the minerals found: the presence of berlinite has been interpreted as diagnostic of burning largely on the basis that the literature on materials and mineralogy suggests that berlinite is normally associated with high temperatures, typical of fire or metamorphism (e.g., Prado-Herrero et al., 2010, indicate that berlinite starts to form in temperatures above $100^{\circ} \mathrm{C}$ and is stable at higher than $550^{\circ} \mathrm{C}$ ). As an example of such reasoning, Sauro et al. (2014), from guano deposits in a cave in Italy, found XRD evidence suggestive of berlinite but question that diagnosis on the assumption that berlinite must require high temperatures. However, we argue that, if microbial action can produce it, berlinite might not be diagnostic of fire, and other evidence would then be required to indicate the provenance. This led us to the question of how burned guano might otherwise be recognized.

The case of guano combustion in Cioclovina Cave does appear to be relatively well supported. However, this is just one example, and this cave is unique and chemically complex, in that it is not a tropical setting (the more common setting for large guano deposits), has huge deposits of phosphate $15-20 \mathrm{~m}$ thick, is also one of the richest deposits of fossil fragments in Europe (Dumitraş et al., 2008), and was extensively mined in the early $20^{\text {th }}$ century. Moreover, Cioclovina Cave is located in central Europe where hominids have been making fires in caves for 500 millennia (Roebroeks, 2006; Roebroeks \& Villa, 2011). Indeed, a $32.5 \mathrm{ka}$ human skull has been found in the cave (Soficaru et al., 2007). This led us to question what burning of samples of guano from more common and simple settings would show.

\section{Research aim}

We suggest that natural spontaneous burning in a cave is an extremely unlikely occurrence and that this should not be posited unless corroborated by significant evidence (so, for example, the presence of berlinite alone should not be considered diagnostic unless accompanied by other evidences of burning, and evidence for the absence of anthropogenic activity). Furthermore, we theorize that a diagnosis of burning (rather than, for example, diagenesis caused by simple chemical or bacterial action) might be relatively easily confirmed by observation of features of the sediment. However, little is published about the effects of burning on the structure and mineral composition of the guano itself. One of the few descriptions that we could find is the Urbani (1996) report, from a cave in Venezuela, that the remnant of burnt guano presented as irregular "slag masses", with metallic luster and amorphous under XRD (implying that no crystalline minerals were present).

Therefore, we set up a simple experiment to test the effects of ignition under several scenarios in order to simulate the natural conditions that might exist in the anoxic conditions of buried guano. We address two questions: i) how does burning affect the morphology of fresh or decayed guano (e.g., how much of the original morphology is preserved after burning); and ii) how does burning affect the mineralogy of fresh or decayed guano (e.g., does burning produce a suite of distinctive or diagnostic minerals)?

\section{METHODS}

Samples of fresh guano from insectivorous bats (predominantly Hipposideros galeritus and $H$. cervinus: Hall et al., 2002 ) were collected from Niah Great Cave, Sarawak, Borneo, and a yellow clayey residuum, the end-product of guano decay, from Deer Cave, Sarawak, Borneo. Based on Onac and White's (2003) suggestion that berlinite in Cioclovina Cave must indicate burning at $350-600^{\circ} \mathrm{C}$, our ignition was at $540^{\circ} \mathrm{C}$ for 18 hours. To simulate anoxic conditions (Onac \& White, 2003, noted that the material was compacted and buried plus sealed under clay), we heated under a nitrogen atmosphere. To simulate burning of semi-decayed guano, we added various permutations of a mix of fresh guano with the clayey residuum. The burned materials were then compared 
with the unburned controls. The tests included: fresh guano unburned and burned; clay residuum unburned and burned; fresh guano plus residuum (50:50) burned; and, since decaying guano-rock interactions often produce sulphates and phosphates (Audra et al., 2019), we burned guano plus reagentgrade $\mathrm{CaSO}_{4}$ (50:50), and guano plus reagent-grade $\mathrm{Ca}\left(\mathrm{H}_{2} \mathrm{PO}_{4}\right)_{2} \cdot \mathrm{H}_{2} \mathrm{O}$.

Materials were examined under binocular microscope, scanning electron microscope (SEM) and energy dispersive spectroscopy (EDS) at Carleton University Nano-Imagining Facility. X-ray diffraction was done by Attard XRD Services, San Diego, US, and one sample in the James Hutton Institute, Dundee, UK. Samples were run on a Philips XRD diffractometer using Copper $\mathrm{K}$ alpha radiation and equipped with a graphite diffracted beam monochromator, with power setting of $40 \mathrm{kV}$ and $30 \mathrm{~mA}$. Patterns were collected using continuous scans from 10 to $60^{\circ} 2$ theta at a step size of $0.02^{\circ} 2$ theta, a time per step of $0.25 \mathrm{sec}$ and a scan speed of $0.08^{\circ} 2$ theta per sec.

\section{RESULTS}

\section{Impact of burning on the morphology of guano: Effect of burning on fresh guano}

Overall differences on the macro- and micro-scale

Figure 1 shows side-by-side, at the same scale, the macro-scale and the micro-scale differences between fresh and burnt guano. The most obvious difference is, of course, colour. The fresh guano has two basic features: i) yellow to dark-brown fragments, many translucent and shiny (several identifiable to the naked eye as insect cuticle); and ii) dark-brown, opaque, compact, elongate pellets. The burned guano is all black, the larger fragments still retaining much of the form and shiny surface, but the smaller particles largely dull and sooty. Grain size differences are also obvious, the fresh guano fragments typically 0.5 to $1.5 \mathrm{~mm}$ to a maximum of $3 \mathrm{~mm}$. The burnt guano has lost much, but not lost all, of its structure: it does retain some large fragments, also up to about $3 \mathrm{~mm}$ maximum, but the majority of grains are smaller than $0.1 \mathrm{~mm}$. The constituents show two obvious differences: the fresh guano includes bat hairs, fragments of plants (e.g., grasses and liverworts - probably fallen from the cave-dwelling swiftlet nests nearby) and fecal pellets; while in the burnt guano none of the easily-combustable material remains, only a few of the fragments are identifiable as insect remains, and no intact fecal pellets can be seen.

\section{Impact on insect remains}

Although burning does reduce much of the guano to non-descript, non-identifiable small grains, a surprizing number of insect parts, although moreor-less damaged, do retain their integrity. The fresh material contains a greater variety of sizes of insect cuticle fragments, and generally larger. The maximum size of insect fragment documented during SEM imaging was about the same for both $(1,700 \mu \mathrm{m})-$ implying that big pieces of insect are not as likely to be destroyed by burning as small ones. Figure 2 shows, side by side for comparison, insect parts that could

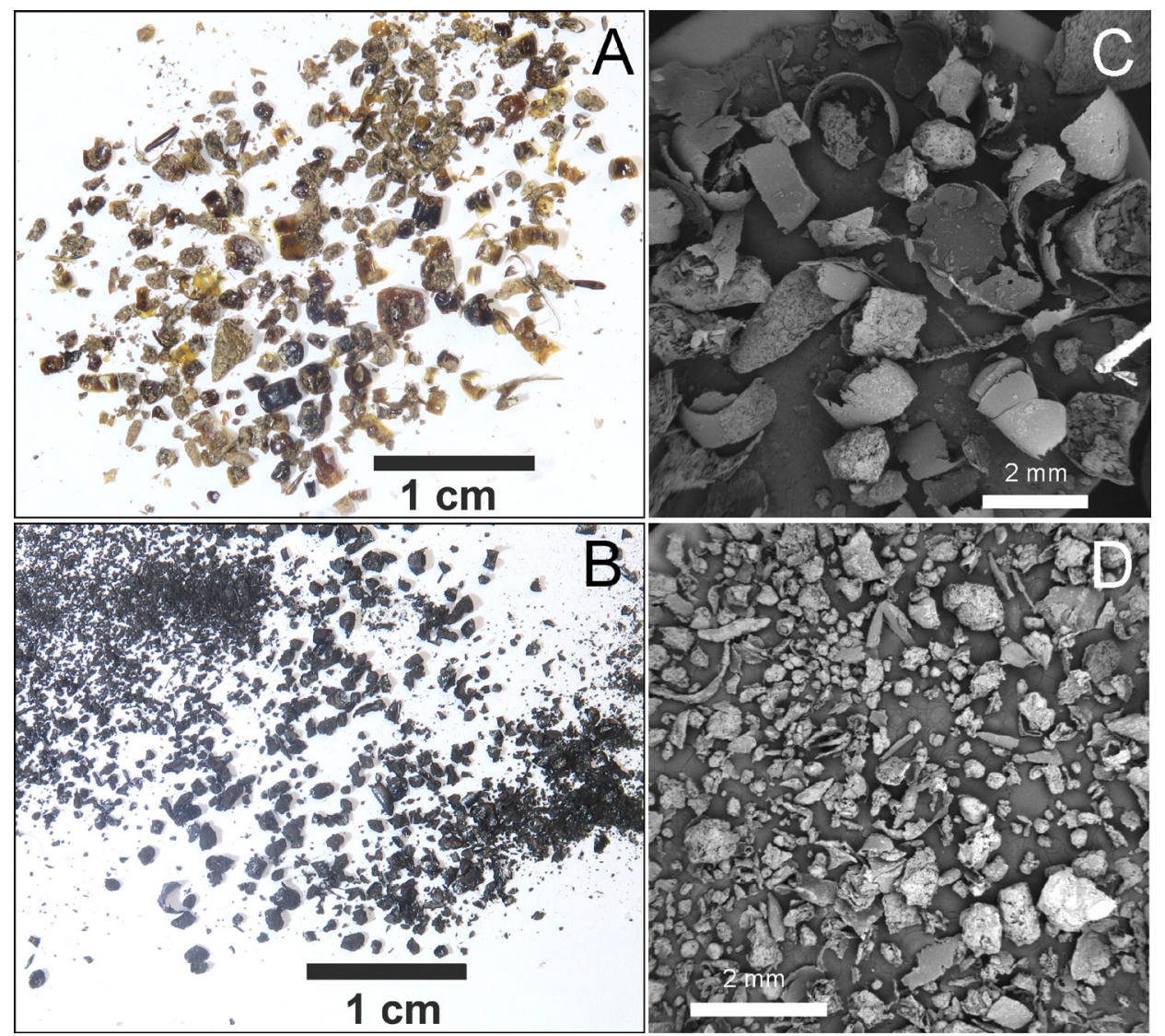

Fig. 1. Comparison of fresh and burnt guano, at the macro and micro levels. A) Fresh macro; B) Burned macro (the numerous tiny particles have been moved out of the way of the larger particles in the centre); C) Fresh micro, SEM; D) Burned micro, SEM. The difference in size of the particles is clear, the fresh presenting large intact fragments, most of which can be confidently identified as insect remains or fecal pellets, and the burnt presenting many more but smaller and fewer identifiable fragments. 
still be identified, although somewhat damaged, in the burnt material (e.g., head, eye, thorax). Although the general pattern seems to be that the smaller fragments in the burnt material are not preserved well enough to allow identification as to potential origin, a few examples were found where delicate material did survive the burning (Fig. 3).

\section{Impact on fecal pellets}

The bat fecal pellets (Fig. 4A, B) are elongate, with rounded tip, $\sim 3 \mathrm{~mm}$ long by $1.2 \mathrm{~mm}$ wide, and made up of insect fragments, 100-200 $\mu \mathrm{m}$ in size, loosely clumped together, and (usually only remnants of a thin, outer coating holding it together. Some of them included small well-rounded mini-pellets (rare, and only found in the fresh guano) $100-200 \mu \mathrm{m}$ in diameter (probably from coprophagous insects: Wurster et al.,
2015). The burnt material had very few remnants of fecal pellets, and the few found were broken.

\section{Impact on nodules}

As well as insect remains and fecal pellets, the guano has some nodules made up of unidentifiable fragments glued together with what appears to be clay. These are up to $\sim 3 \mathrm{~mm}$ in all dimensions, and of lumpy form. These survive the burning well, although blackened, with morphology and frequency about the same in the fresh and the burnt material (Fig. 4C, D).

\section{Impact of burning on the morphology of guano: Effect of burning on decayed guano}

The clayey residuum from decayed guano shows no evidence of any insect parts, or of fecal pellets or of nodules. It is made up of more-or-less clumped
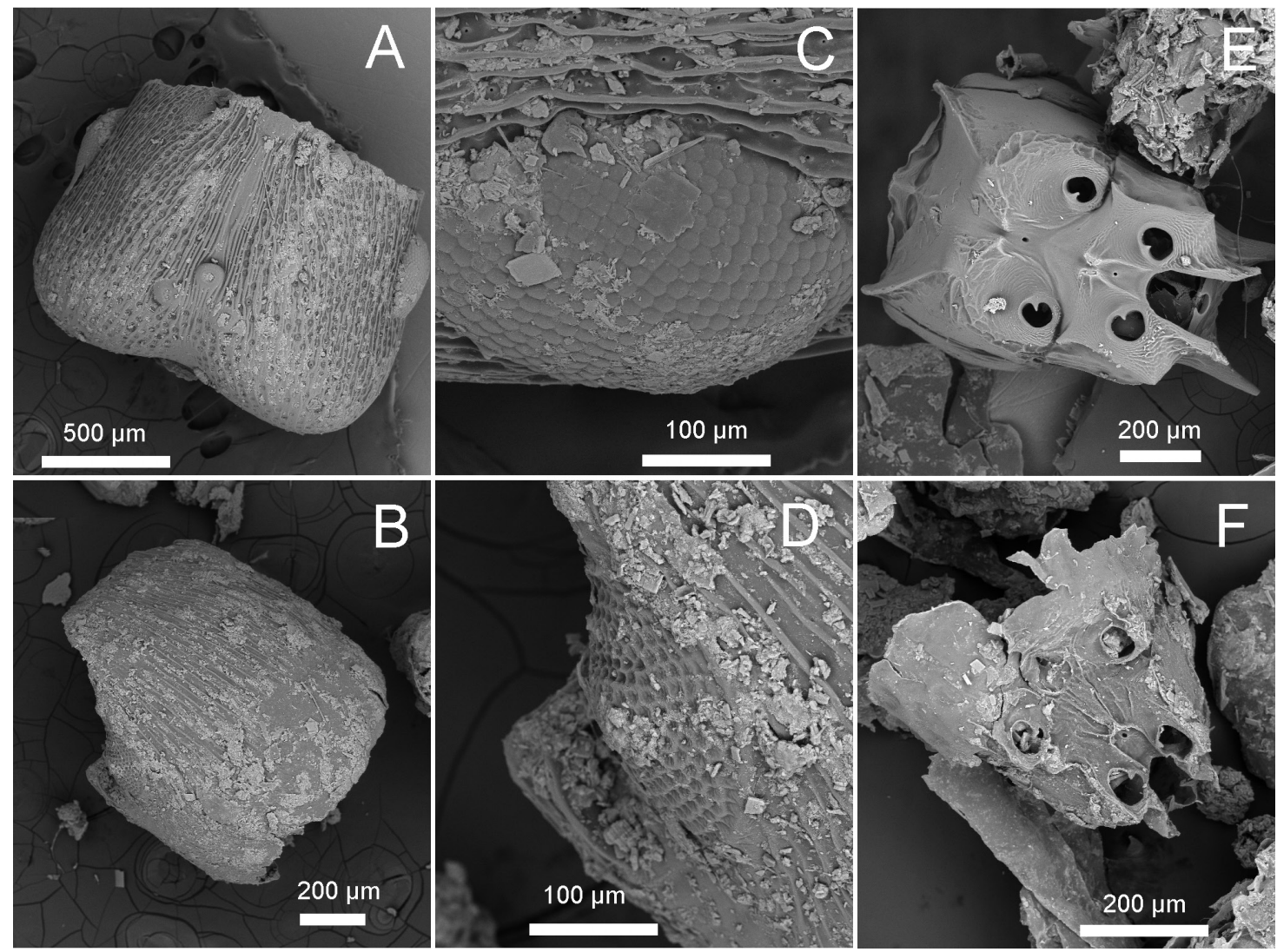

Fig. 2. Head of insect, with side-mounted compound eyes from (A) fresh guano, and (B) burned guano. Detail of compound eye and striations on carapace from $(C)$ fresh guano, and $(D)$ burnt guano. Preservation is better in the fresh material and the facets of the compound eye in the burnt material appear to have collapsed. Thorax of similar species from $(E)$ fresh guano, and $(F)$ damaged example from burnt guano

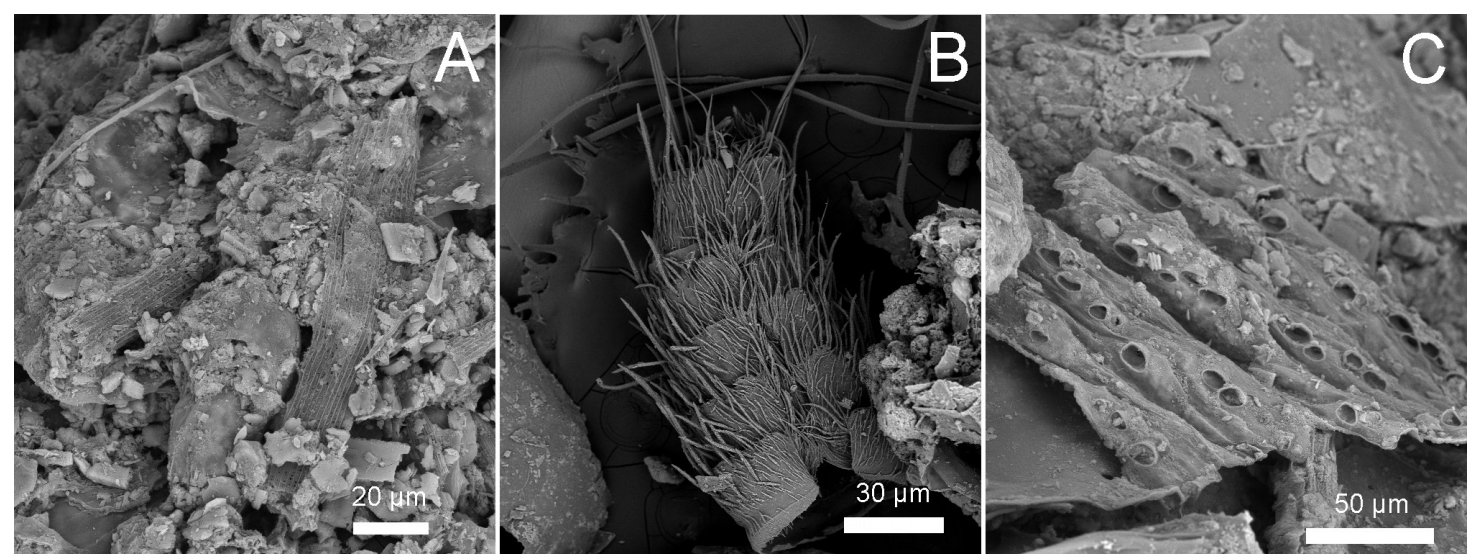

Fig. 3. Rare examples of delicate structures still apparent in burnt guano. 


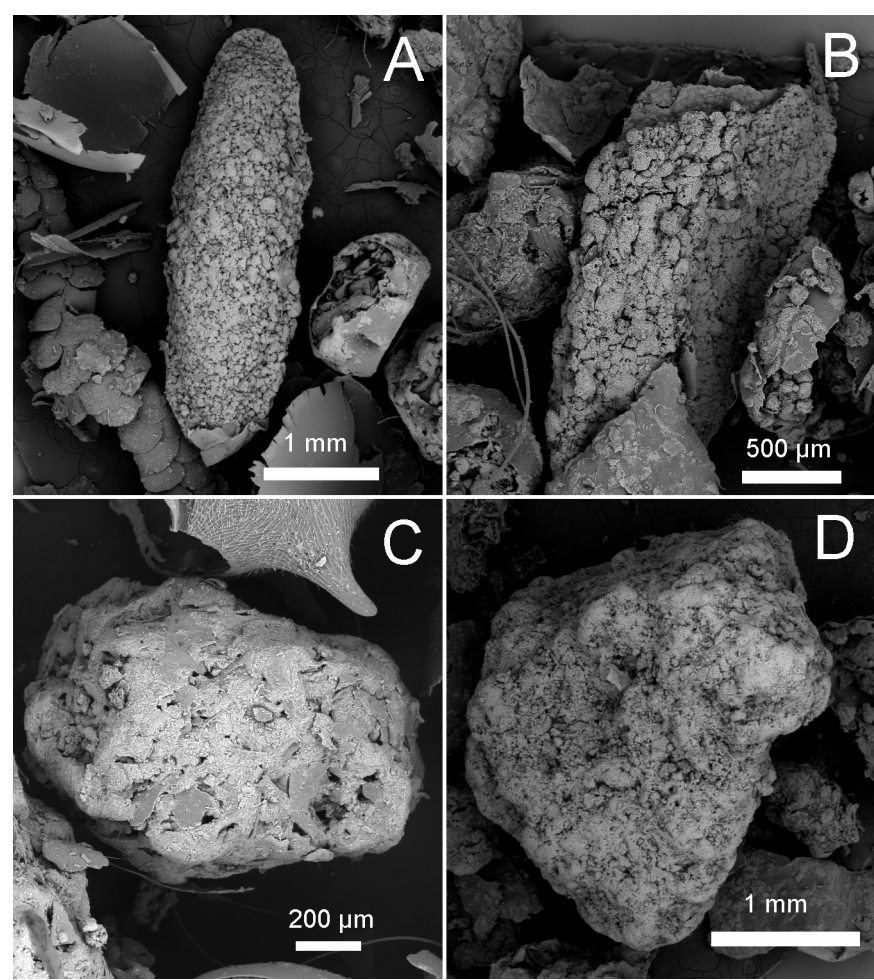

Fig. 4. Fecal pellets and clay nodules. A) Intact elongate fecal pellet (common) from the fresh material (the interesting feature with overlapping scales to the left is a liverwort, probably dropped from a swiftlet nest, tentatively identified as one of the sixty seven Frullania sp. that have been identified in Malaysia); B) Broken piece of fecal pellet (rare) from the burnt sample; C) Clay nodule from the fresh material; D) Clay nodule from the burnt material.

unidentified tiny particles and many crystals (details of which are presented in next section). Figure 5 shows an overview of the residuum. Burning had little visible effect on the overall morphology.

\section{Mineral components of guano}

Mineral components of the fresh guano

The majority of the material in fresh guano is simply carbon-based organic, and non-crystalline. However, successful XRD analyses confirm the presence of crystals, and under SEM many clear crystals can be picked out.

Two main types of crystals are apparent. The most obvious are relatively large platy-tabular crystals (Fig. 6A). Although overshadowed in prominence by the large insect remains, these crystals can be found scattered around on surfaces. Many of these present as two plates side-by-side, looking rather like an open book (hence our moniker: "open-book" crystal). The "pages" are around 20-30 $\mu \mathrm{m}$ tall, and 15-20 $\mu \mathrm{m}$ wide. Each shows an interesting feature: thickening along the one side of the "page". EDS results show almost balanced $\mathrm{Ca}$ and $\mathrm{S}$, and negligible $\mathrm{P}$ (Table 1). Although this crystal morphology has rarely been illustrated in the literature, the interpretation as gypsum - $\mathrm{Ca}\left(\mathrm{SO}_{4}\right) \cdot 2 \mathrm{H}_{2} \mathrm{O}$ - was confirmed by XRD (Table 2).

The other major crystalline component is tiny lenticular-acicular crystals that in places form a mat between larger particles and are scattered on many surfaces (Fig. 6B). These are on average 1 to 5 microns long, and 0.1 microns thick. EDS results show almost balanced $\mathrm{Ca}$ and $\mathrm{P}$, and negligible $\mathrm{S}$. This result is most consistent with brushite $-\mathrm{Ca}\left(\mathrm{PO}_{3} \mathrm{OH}\right) \cdot 2 \mathrm{H}_{2} \mathrm{O}-\mathrm{a}$ commonly reported component of guano (Hill \& Forti, 1997), or perhaps whitlockite $-\mathrm{Ca}_{9} \mathrm{Mg}\left(\mathrm{PO}_{3} \mathrm{OH}\right)\left(\mathrm{PO}_{4}\right)_{6}$ - reported as dominant in Niah Great Cave guano by Wurster et al. (2015). Most of the published images of brushite crystals show a blunt-ended acicular to

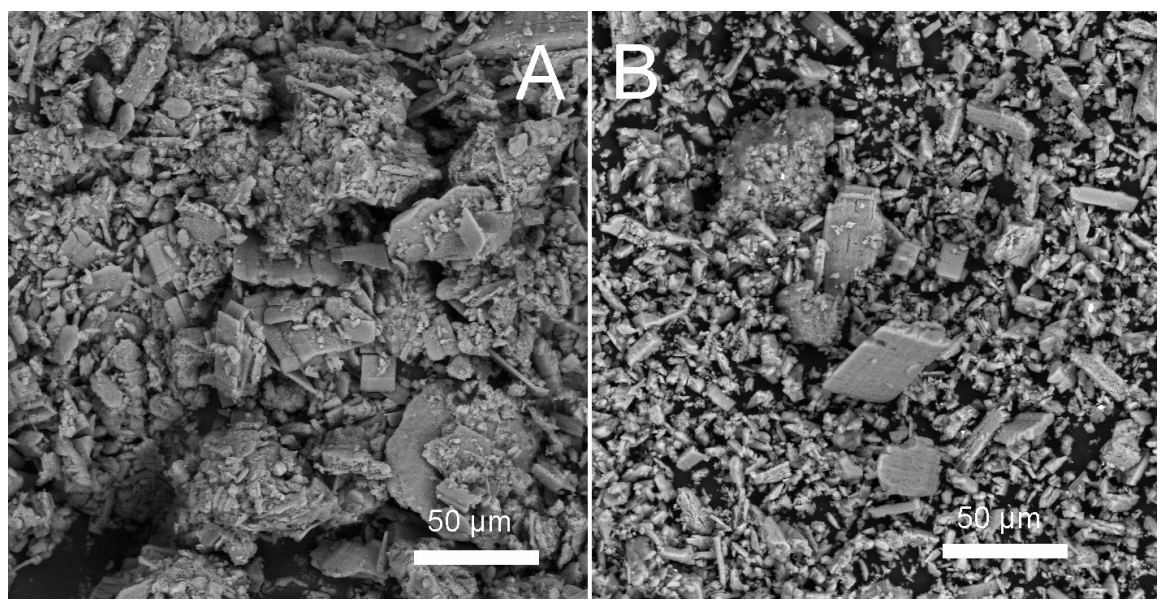

Fig. 5. Overview of clay residuum from decayed guano. This presents as a fine-grained powdery material, of mostly nondescript morphology (the flat crystals, identified as gypsum, have the clearest structure - more details below). No insect parts or fecal pellets are apparent. Burning has little effect on the overall morphology ( $A$ is unburned, $B$ is burned).

tabular form. Ours are very small and taper at the ends. However, the crystal form of brushite varies greatly with conditions of formation (such as $\mathrm{pH}$ and concentration of $\mathrm{HPO}_{4}$ ions and $\mathrm{Ca}$ ions: Suryawanshi \& Chaudhari, 2014; Toshima et al., 2014; Malikova et al., 2018).

$\mathrm{XRD}$ analysis also reports a small component of quartz $-\mathrm{SiO}_{2}$. However, no obvious quartz crystals were observed under SEM. This may represent dust brought in on bat pelage (Wurster et al., 2015) or phytoliths from the guts of the bat-ingested herbivorous insects (Parr, 2006; Rodríguez-Cintas $\&$ Cabanes, 2017). However, because the silica of phytoliths, being non-crystalline (Yang et al., 2020) and thus not detectable by XRD, the phytoliths may have dissolved and been re-precipitated

\section{Mineral components of the decayed guano}

The fine-grained clayey residuum was unstable under the electron beam of the SEM, and thus 

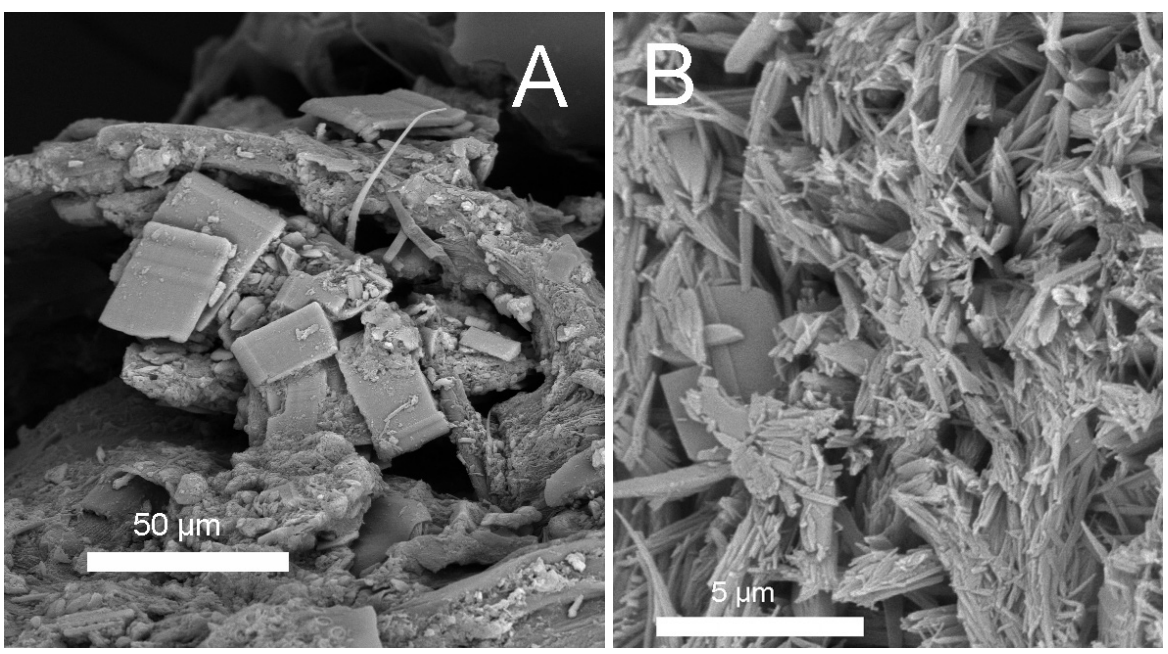

Fig. 6. SEM of the crystalline components of the fresh guano (note difference in scale). A) Large platy crystals of gypsum; B) Small acicular crystals identified by EDS as most likely brushite.

Table 1. EDS results on large (A) crystals and small $(B)$ crystals.

\begin{tabular}{|c|c|c|c|c|c|c|c|c|c|}
\hline $\begin{array}{l}\text { A. Large platy } \\
\text { crystals }\end{array}$ & Atomic \% & $\begin{array}{c}\text { Ratio to } \\
\text { Ca }\end{array}$ & Atomic \% & $\begin{array}{c}\text { Ratio to } \\
\text { Ca }\end{array}$ & \begin{tabular}{|c|} 
B. Small \\
acicular crystals
\end{tabular} & Atomic \% & $\begin{array}{c}\text { Ratio to } \\
\mathbf{C a}\end{array}$ & Atomic \% & $\begin{array}{c}\text { Ratio to } \\
\text { Ca }\end{array}$ \\
\hline & Fresh & & Burnt & & & Fresh & & Burnt & \\
\hline Oxygen & 85.7 & 12 & 71.2 & 5 & Oxygen & 82.4 & 9 & 62 & 3 \\
\hline Phosphorus & 2.0 & 0 & 0.4 & 0 & Phosphorus & 6.8 & 1 & 14 & 1 \\
\hline Sulfur & 5.0 & 1 & 13.2 & 1 & Sulfur & 1.4 & 0 & 3 & 0 \\
\hline Potassium & 0.0 & 0 & 0.3 & 0 & Potassium & 0.1 & 0 & 1 & 0 \\
\hline Calcium & 7.4 & 1 & 14.9 & 1 & Calcium & 9.2 & 1 & 20 & 1 \\
\hline
\end{tabular}

Table 2. XRD results.

\begin{tabular}{|c|c|c|}
\hline Material & Mineral/Compound Name & Chemical Formula \\
\hline Guano - not burned & $\begin{array}{l}\text { Gypsum } \\
\text { Quartz }\end{array}$ & $\begin{array}{c}\mathrm{Ca}\left(\mathrm{SO}_{4}\right) \cdot 2 \mathrm{H}_{2} \mathrm{O} \\
\mathrm{SiO}_{2}\end{array}$ \\
\hline Guano - burned & $\begin{array}{c}\text { Anhydrite } \\
\quad \text { Giniite } \\
\text { High-Mg calcite }^{1} \\
\text { Whitlockite }(\mathrm{Mn})\end{array}$ & $\begin{array}{c}\mathrm{Ca}\left(\mathrm{SO}_{4}\right) \\
\mathrm{Fe}^{2+} \mathrm{Fe}^{3+}\left(\mathrm{PO}_{4}\right)_{4}(\mathrm{OH})_{2} \cdot 2 \mathrm{H}_{2} \mathrm{O} \\
\left(\mathrm{Mg}_{0.1} \mathrm{Ca}_{0.9}\right)\left(\mathrm{CO}_{3}\right) \\
\mathrm{Ca}_{9} \mathrm{Mn}_{2}\left(\mathrm{PO}_{3} \mathrm{OH}\right)\left(\mathrm{PO}_{4}\right)_{6}\end{array}$ \\
\hline Decayed guano - not burned & $\begin{array}{l}\text { Gypsum } \\
\text { Brushite } \\
\text { Variscite }\end{array}$ & $\begin{array}{c}\mathrm{Ca}\left(\mathrm{SO}_{4}\right) \cdot 2 \mathrm{H}_{2} \mathrm{O} \\
\mathrm{Ca}\left(\mathrm{PO}_{3} \mathrm{OH}\right) \cdot 2 \mathrm{H}_{2} \mathrm{O} \mathrm{Al}\left(\mathrm{PO}_{4}\right) \cdot 2 \mathrm{H}_{2} \mathrm{O}\end{array}$ \\
\hline Decayed guano - burned & $\begin{array}{l}\text { Anhydrite } \\
\text { Brushite } \\
\text { Bayerite }\end{array}$ & $\begin{array}{c}\mathrm{Ca}\left(\mathrm{SO}_{4}\right) \\
\mathrm{Ca}\left(\mathrm{PO}_{3} \mathrm{OH}\right) \cdot 2 \mathrm{H}_{2} \mathrm{O} \\
\mathrm{Al}(\mathrm{OH})_{3}\end{array}$ \\
\hline Guano + Decayed guano $+\mathrm{CaSO}_{4}-$ burned & $\begin{array}{l}\text { Anhydrite } \\
\text { Low-Mg calcite }^{1} \\
\text { Bassanite } \\
\text { Augelite } \\
\text { Tridymite }\end{array}$ & $\begin{array}{c}\mathrm{Ca}\left(\mathrm{SO}_{4}\right) \\
\left(\mathrm{Mg}_{0.03} \mathrm{Ca}_{0.97}\right)\left(\mathrm{CO}_{3}\right) \\
\mathrm{Ca}\left(\mathrm{SO}_{4}\right) \cdot 0.5 \mathrm{H}_{2} \mathrm{O} \\
\mathrm{Al}_{2}\left(\mathrm{PO}_{4}\right)(\mathrm{OH})_{3} \\
\mathrm{SiO}_{2}\end{array}$ \\
\hline Guano $+\mathrm{Ca}\left(\mathrm{H}_{2} \mathrm{PO}_{4}\right)_{2} \cdot \mathrm{H}_{2} \mathrm{O}-$ burned & $\begin{array}{c}\text { Graphite } \\
\text { Strontium-“apatite"2 } \\
\text { Calcite } \\
\text { Oldhamite } \\
\text { Calcium metaphosphate }\end{array}$ & $\begin{array}{c}\mathrm{C} \\
\mathrm{Sr}_{5}\left(\mathrm{PO}_{4}\right)_{3} \cdot(\mathrm{OH}) \\
\mathrm{Ca}\left(\mathrm{CO}_{3}\right) \\
\mathrm{CaS} \\
\mathrm{Ca}\left(\mathrm{PO}_{3}\right)_{2}\end{array}$ \\
\hline
\end{tabular}

${ }^{1}$ The designations "High-Mg" calcite, or "Low-Mg" calcite do not appear in the IMA list of minerals (IMA, 2021). However, since calcium can be substituted by $\mathrm{Mg}$ to varying extents, the terms are regularly used in the literature; e.g., see discussion in Stanienda-Pilecki (2018).

${ }^{2}$ The compound strontium hydroxide phosphate may be called Strontium-"apatite", a term that is not IMA approved but, because Sr substitutes for $\mathrm{Ca}$ in the apatite group of minerals, is often used in the literature (e.g., Chakhmouradian et al., 2002). It is used thus here, but in quotation marks because apatite is not a single mineral.

inimical to acquiring high-quality images at higher magnifications. The particle sizes range from $<1 \mu \mathrm{m}$ up to about $50 \mu \mathrm{m}$, the smaller ones of indeterminate form, the larger ones of crystalline form. The majority of the large crystals are gypsum - of the same "openbook" form with thickened ends (Fig. 7A) as in the fresh guano, and about the same dimensions, but much more common. XRD confirmed gypsum as the most common component. Less common are larger crystals, up to about $50 \mu \mathrm{m}$ in length, and almost fibrous in appearance (Fig. 7B). The identification as most likely brushite ( $c f$ Fig. 5 of Tămaş, et al., 2014; Onac, pers. comm., 2020) was confirmed by XRD analysis. The aluminum phosphate mineral, variscite, was identified by XRD, although not observed by SEM. 

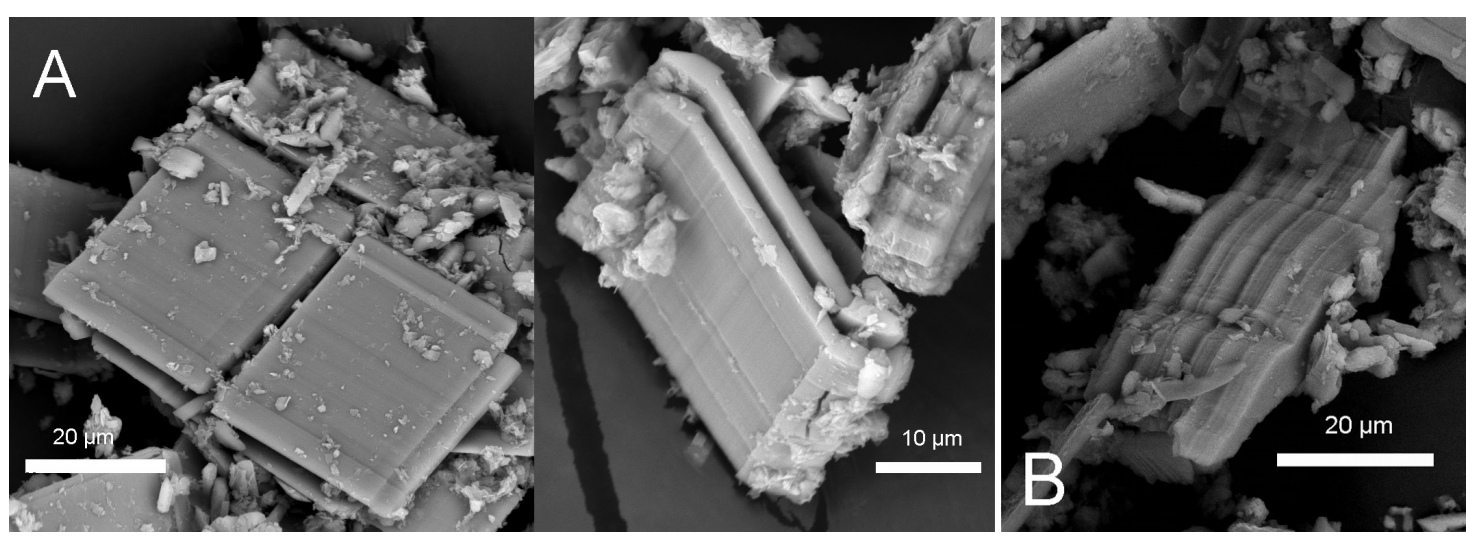

Fig. 7. SEM of the crystalline components of the decayed guano, clayey residuum. A) platy-tabular crystals of gypsum (common); B) Large fibrous crystals identified as most likely brushite (rare).

\section{Impact of burning on the mineral components}

The burnt guano shows only a few crystalline forms scattered about (at about the same frequency as in the fresh). Several examples of the "open-book" large platy-tabular crystals were found. However, these were more-or-less damaged (Fig. 8A). XRD analysis indicated anhydrite rather than gypsum. The cracked and striated appearance of the plates indicates the process of dehydration/alteration. Many of the small particles can be seen to be fragmentary remains of the breakup of the platy crystals. EDS showed the same proportion of $\mathrm{Ca}$ and $\mathrm{S}$ as in the fresh material, but less oxygen (which is consistent with loss of $\mathrm{H}_{2} \mathrm{O}$ ). XRD analysis indicated anhydrite (Table 2).

The burnt guano also has the tiny acicular crystals (Fig. 8B) scattered around on surfaces and in places forming a thin mat which fills gaps (in the same general distribution as the fresh guano). These have roughly the same appearance, distribution, and size as in the fresh guano, but again are damaged in that they look less clean, and a little more fragmented along their long axes. EDS analysis showed the same $1: 1$ proportion of $\mathrm{Ca}$ and $\mathrm{P}$, but less oxygen than in the fresh material - again consistent with loss of $\mathrm{H}_{2} \mathrm{O}$, and more consistent with whitlockite than brushite, a judgement confirmed by XRD results (Table 2).

The XRD results indicated gypsum as the dominant mineral in the non-burnt material (both fresh guano and decayed guano residuum) with just a little quartz in the fresh guano. The most obvious impact of burning was to transform the gypsum to anhydrite, the most abundant mineral in the burnt material. The brushite was transformed to whitlockite. The decayed guano already has brushite and variscite. Burning transformed the aluminium phosphate of the variscite to the aluminium hydroxide of bayerite

A few other interesting minerals/compounds were produced by burning. The burn test of fresh guano alone yielded small quantities of the iron phosphate mineral giniite, and High-Mg calcite (see footnote to Table 2 for discussion of mineral terminology). Mixing fresh and decayed guano with reagent $\mathrm{CaSO}_{4}$ yielded the aluminum phosphate augelite (presumably from the transformation of variscite), and the silicon dioxide tridymite (presumably from the transformation of quartz). The final test, adding reagent $\mathrm{Ca}\left(\mathrm{H}_{2} \mathrm{PO}_{4}\right)_{2} \cdot \mathrm{H}_{2} \mathrm{O}$ yielded graphite, strontium-"apatite", calcite, and the calcium sulfide mineral, oldhamite (presumably by loss of all $\mathrm{H}$ and $\mathrm{O}$ from gypsum), in addition to the $\mathrm{Ca}\left(\mathrm{PO}_{3}\right)_{2}$ produced by loss of $\mathrm{H}_{2} \mathrm{O}$ from the added reagent.

\section{DISCUSSION}

\section{Colour}

The presence of blackened materials may be good clue to burning (e.g., see Kaal et al., 2021). However, colour alone may not be diagnostic. For example, humification through aerobic microbial activity yields dark brown material (Hänninen, 2017); Sebela et
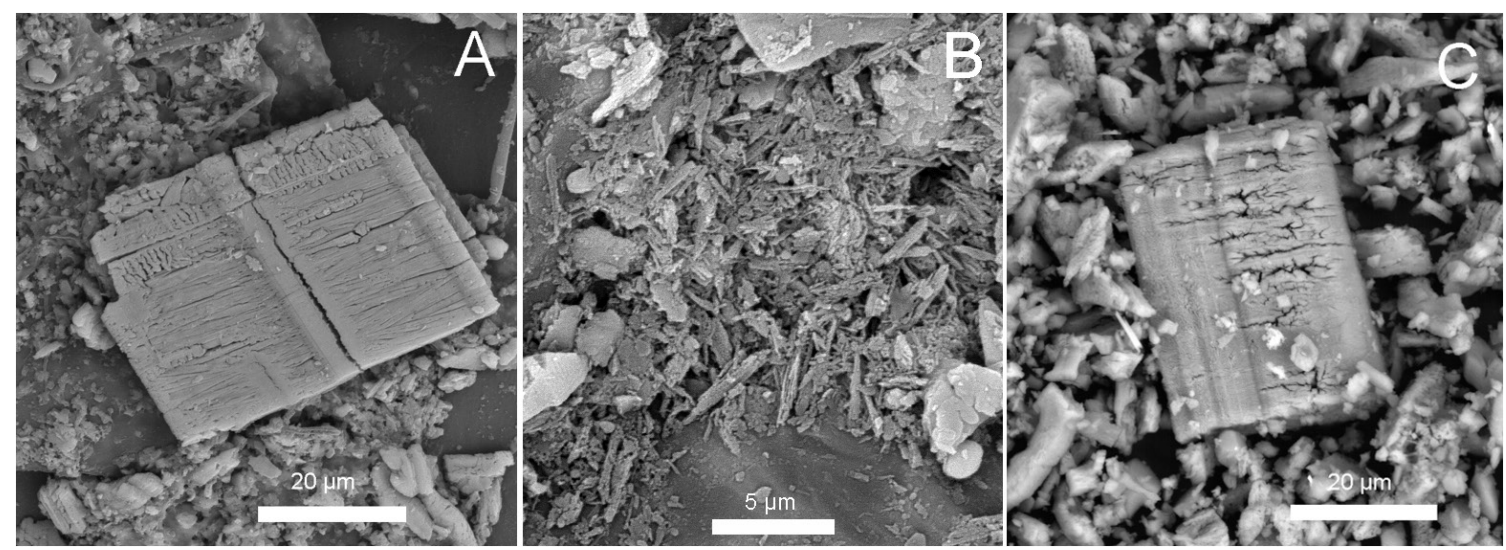

Fig. 8. SEM of the crystalline components of the burnt guano. A) Large platy crystals, very similar to the gypsum from fresh guano, but damaged by many cracks and striations from the process of dehydration to anhydrite (as shown by XRD); B) Tiny acicular crystals similar to the small crystals in fresh guano. Size is not affected by burning, but the burned crystals have many cracks, probably from dehydration of brushite to whitlockite: C) Burnt residuum, showing damaged large platy anhydrite crystals, very similar to A, along with many fragments of broken anhydrite. 
al. (2015) discuss various black deposits in caves of Slovenia, some from natural microorganism activity and some from human activity; Shahack-Gross et al. (2004) describe a horizon of microbially-decomposed guano that is black; Urbani (1996) reports hydroxylapatite layers in Venezuela as dark-brown to black; Audra et al. (2019) note that vertical leaching of Mn compounds may form a black accumulation horizon; and Gázquez et al. (2011) describe black horizons of Mn-Fe deposits in Spain.

\section{Morphology and composition of guano}

The guano chosen is a nondescript insectivorous bat guano similar to the many published accounts of guano from geologically-simple limestone cave settings. The overall appearance of our guano is not significantly different from published descriptions: e.g., ShahackGross et al. (2004) describe insectivorous bat guano from four cave sites in Israel as dark in colour, composed of small fecal pellets, mainly of chitin, with some clay, and some microscopic crystals of brushite. Similarly, the minerals in our guano and decayed guano residuum are consistent with the standard minerals widely reported from guano (e.g., gypsum, whitlockite, hydroxylapatite, brushite, ardealite, monetite, taranakite, crandallite, and variscite: Hill \& Forti, 1997; Onac \& Forti, 2011; Queffelec et al., 2018).

\section{Morphology of crystals}

Although not directly significant for this study, the morphology of these gypsum crystals is interesting ("open-book" with rimmed edges), and, judging from the scarcity of comparable forms in the literature, appears to be somewhat rare. It is well known that gypsum can take on a great variety of crystal shapes. However, our exhaustive search for examples of natural gypsum crystals of similar form to ours turned up very few: one is from De Waele et al. (2017) showing anhydrite from the mineralogicallyextraordinary salt caves in the Atacama Desert, with tabular form somewhat similar to ours, but appearing to lack the rimmed edge. The details of form and synthetic production methods are of great interest to material scientists: in one example, picked out of legion, Bard and Bilal (2011) document the changes in morphology with temperature change, $\mathrm{pH}$ change, rate of introductions of calcite suspension, etc. Of the synthetic examples in the literature, the closest we could find to our form was precipitated in presence of a phosphatic additive (specifically, sodium-hexameta-phosphate: Rahman, 2013) - perhaps close to the natural process of biological digestion of guano in the presence of calcium and sulphate.

\section{Damaged crystals}

The damage to the gypsum crystals (cracks and striations followed by breakage of crystals rather than slow re-crystallization to the new mineral) is most likely related to the rapidity of the dehydration and this damage might be one of the key features by which burning may be recognized. Published images of anhydrite crystals from caves do not show such damage; for example, the images of anhydrite from slow evaporation in the Atacama Desert (De Waele et al., 2017) do not show crystal damage such as we have seen. Transformation of gypsum to bassanite and finally to anhydrite is reported as beginning at about $100^{\circ} \mathrm{C}$ (Cressey, 2005), with complete transformation by $600^{\circ} \mathrm{C}$ (Kilic \& Kilic, 2007). While the overall crystal morphology differs from ours, Leskeviciene et al. (2010) show similarly cracked and damaged crystals of anhydrite, from burning of gypsum at $800-900^{\circ} \mathrm{C}$.

\section{Differentiating burnt guano from decayed guano}

From the suite of minerals produced, it may be difficult to distinguish burning of guano from simple decay of guano over time (in combination with microbial action and rock-interactions). Decay processes produce a wide variety of authigenic minerals, including gypsum. The suite of minerals produced at various stages of guano decay generally contains complex phosphates, of which the most common are hydroxylapatite, brushite, ardealite, taranakite and variscite (Audra et al., 2019). For example, Queffelec et al. (2018) report minerals from the decay of insectivorous bat guano in France to include hydroxylapatite, brushite, ardealite, taranakite as well as gypsum, francoanellite, monetite, and newberyite. Wurster et al. (2015) found gypsum, bassanite, leucophosphite, spheniscidite, and variscite in guano of Borneo (although that study was complicated by the intermingling of bat and swiftlet bird guano). Whitlockite, spheniscidite, montgomeryite are also reported from various sites, some of which are complicated by the presence of ash and bone material (Karkanas et al., 2002; ShahackGross et al., 2004; Dumitraş et al., 2008).

In considering the list above, it is apparent that most of the minerals we found (gypsum, brushite, variscite, whitlockite, bassanite, Sr-“apatite") are simply those produced by guano alteration and interactions with rock, and are thus not diagnostic of burning. The other minerals/compounds found in the burnt material are discussed below.

\section{Minerals produced by burning}

The most controversial question is whether the minerals produced by burning are diagnostic, and, to a lesser extent, whether fire can be deduced from the presence of just one significant mineral, or if more than one should be required. The search for an infallible diagnostic mineral is fraught with danger because several of the exotic minerals associated with high temperatures can also be produced at low temperatures by bacterial mediation or weathering (see below). Note that the absence of literature about weathering or microbial action in the synthesis of a particular mineral may only be ancillary support for an obligate high temperature origin; alternatively, it may simply imply that this has not yet been studied/ reported.

The guano-burning experiment reported here produced a few interesting minerals (but neither of the two high temperature minerals reported from Cioclovina Cave, berlinite and hydroxyellestadite). 
We investigated whether these might be potential contenders for a diagnostic fire-indicator mineral.

- Giniite: Burning fresh guano alone, in addition to the obvious crystal damage to the crystals (both of gypsum and of brushite), yielded the iron phosphate hydroxide mineral giniite, $\mathrm{Fe}^{2+} \mathrm{Fe}^{3+}\left(\mathrm{PO}_{4}\right)_{4}(\mathrm{OH})_{2} \cdot 2 \mathrm{H}_{2} \mathrm{O}$, a mineral not reported from any cave setting. It was not discovered until 1980, in association with pegmatites (Mindat, 2021a) and is synthetically prepared hydrothermally (e.g., $250^{\circ} \mathrm{C}$, Gonçalves et al., 2017). While this mineral is obviously created in high temperature situations, it is also found in association with biological systems. For example, it is found in iron-rich sediments in Yellowstone acidic thermal springs (Mathur et al., 2007), in association with a diverse array of gram-positive iron oxidizers. The mineral can also be synthesized at low temperatures, by microbial mats in polysaccharide matrix. Nedkov et al. (2016) used biotechnology to create biogenic ferrian giniite based on laboratory cultivated Leptothrix bacteria (taken from a mountain stream), cultivated in medium for 14 days at $20^{\circ} \mathrm{C}$. Thus giniite cannot be considered as diagnostic of burning.

- Bayerite: Burning decayed guano alone yielded the aluminium hydroxide bayerite, $\mathrm{Al}(\mathrm{OH})_{3}$. This is the monoclinic polymorph of the aluminium hydroxide gibbsite - an important component of bauxite. Although rare in nature, it is found typically as weathered crusts on bauxite (Mindat, $2021 b)$. It forms in neutral to alkaline conditions, in soils (Scheinost, 2005), and is thus not an indicator species for high temperatures. Its closely-related polymorph, gibbsite, is extremely common in caves, usually in bauxite regions (Hill \& Forti, 1997).

- Augelite: Burning guano with added $\mathrm{CaSO}_{4}$ yielded the aluminium phosphate augelite, $\mathrm{Al}_{2}\left(\mathrm{PO}_{4}\right)(\mathrm{OH})_{3}$. This is typically formed by metamorphism of phosphate-bearing sediments and hydrothermal ore deposits, is related to variscite, and occurs in association with berlinite (Anthony et al., 2000). Berlinite breaks down at lower temperatures to augelite. While we did not find any publications claiming the direct creation of augelite from bacterial action, most publications on phosphorites emphasise the importance of bacterial mats (e.g., Dar et al., 2017). Augelite has not been reported from any cave, but has been reported in soils and sediments: weathering in alkaline environments yields augelite, although rare, as the end product (from wavellite) of interaction of clay minerals with phosphate solutions (Nriagu, 1976); and lateritic weathering of calcium fluorapatite in soils creates augelite, amongst other minerals (Flicoteaux \& Lucas, 1984). Thus augelite may form at both high and ambient temperatures.

- Tridymite: Burning guano with added $\mathrm{CaSO}_{4}$ also yielded the silicate tridymite, $\mathrm{SiO}_{2}$. This is a high temperature polymorph of quartz and common in volcanic rocks, but can form at lower temperatures (Deer et al., 2004; Mindat, 2021c) in cavities infillings, and marine sedimentary rocks. Hill and Forti (1997) also note that it can form at low temperatures, for example, during phosphatization of clay minerals.

- Strontium "apatite": Burning guano with added $\mathrm{Ca}\left(\mathrm{H}_{2} \mathrm{PO}_{4}\right)_{2} \cdot \mathrm{H}_{2} \mathrm{O}$ yielded Sr-"apatite", $\mathrm{Sr}_{5}\left(\mathrm{PO}_{4}\right)_{3} \cdot(\mathrm{OH})$ (or strontium hydroxylapatite: e.g. Ma et al., 2018). Strontium is one of the most common substitutes in the apatite mineral group (Rakovan and Hughes, 2000). Strontium "apatite" is associated with alkali pegmatites but is not high temperature obligate: e.g., Ma et al. (2018) synthesised it at $\sim 30-50^{\circ} \mathrm{C}$.

- Oldhamite: Burning guano with added $\mathrm{Ca}\left(\mathrm{H}_{2} \mathrm{PO}_{4}\right)_{2} \cdot \mathrm{H}_{2} \mathrm{O}$ also yielded the calcium sulphide, oldhamite, CaS. Although reported from hydrothermal caves (Hill \& Forti, 1997) and created by thermal metamorphism of calcite in carbonaceous meteorites (Haberle \& Garvie, 2017), oldhamite might still not be diagnostic of burning, since, as Hill and Forti (1997) note, anaerobic bacterial reduction can reduce sulphates to sulphites. For example, sulphatereducing bacteria are being used to remediate gypsiferous soils, or gypsum waste (Kijjanapanich et al., 2014).

- Graphite: Burning guano with added $\mathrm{Ca}\left(\mathrm{H}_{2} \mathrm{PO}_{4}\right)_{2} \cdot \mathrm{H}_{2} \mathrm{O}$ also yielded graphite. Graphite might well be the only mineral that is relatively unambiguously indicative of burning. We found only one report of graphite in guano that is not associated with burning: Bird et al. (2007) reported, from a cave in the Philippines, that lithogenic graphite, from weathering of the marble walls of the cave, contributed some graphite to the guano. Otherwise graphite is always indicative of fire, usually anthropogenic, and usually of materials, such as wood or grass, introduced to the cave (as indicated, for example, by the phytoliths found therein: Sudbury, 2010). Note that the mineral graphite is not a single crystal, but has a complex crystallographic structure and includes several unstructured carbon phases. $\mathrm{XRD}$ is not the most effective tool for detection of many phases of carbon. Note also that XRD results may be indicative of graphene or graphitelike micro-crystalline substances rather than true graphite. We are relatively confident that our XRD spectrum, with a clear set of peaks rather than generalized wide hills (e.g., Popova, 2017), is not of graphene, but it may represent graphite-like micro crystals.

The conclusion to this part of the study is that, of the potential high temperature minerals/compounds we created (giniite, bayerite, augelite, tridymite, strontium "apatite", oldhamite), none is immune from potential synthesis in low temperature conditions by weathering or bacterial action. The question arises, where several high temperature minerals co-exist, of whether there is a threshold number beyond which it is more likely that the suite was created by fire than by microbial action. Although these minerals are not normally reported in naturally- decayed guano, 
and their presence individually is not diagnostic of burning, it could be argued that the presence of a suite of high temperature minerals such as these, rather than just a single high temperature mineral, could provide reasonably strong evidence for burning. However, it could equally be argued that this simply indicates a suite of complex microbial processes (such as might occur in the extremely complex biology and biochemistry of decaying guano).

The only mineral unquestionably (in our case) from burning is graphite. It is of interest that graphite was produced in only one, and not, as expected, in each, of our burning experiments. The chitin may more commonly change to amorphous carbon (Judai et al., 2016) which would not be detected by XRD. An interesting aside here is that the breakdown products of burning chitin is of relevance to researchers of urban and indoor air quality because chitin is regularly burned in grilling/charring of crustacean seafood. The dominant thermal breakdown product is acetamidodeoxyglucosan - 1,6-anhydro-2-acetamido2-deoxyglucose - a compound that is proposed, by Simoneit et al. (2000), as a specific indicator for chitin burning emissions.

Research on the forms of pyrogenic carbon suggest that this may be a key to understanding whether guano has indeed burned, and led us to the idea that differentiation of the structure of the carbon, in particular the arrangement of aromatic rings, might well be a diagnostic tool for assessment of pyrogenicity of a deposit. For example, Wolf et al. (2013), by analysis of the chemical signature of charcoals, were able to differentiate, and thereby reconstruct, the temperature of maximum heating. The structure of $\mathrm{C}$ varies with the temperature of pyrolysis, pyrolysed biochar generally showing more organization the higher the temperature (Wiedemeier et al., 2015). Pyrogenic carbon has two aromatic $\mathrm{C}$ phases - the amorphous (randomly arranged aromatic rings) and the crystalline phase (turbostratically arranged, condensed polyaromatic sheets) - both of which are influenced by pyrolysis conditions. Wiedemeier et al. (2015) review the various analytical techniques to allow differentiation of the degree of organization of carbon aromatic rings, specifically the aromaticity and the degree of aromatic condensation, since these will allow reconstruction of the highest temperature of char formation. These properties will vary with precursor materials, but, if guano ignition is to be proven, the chemistry of carbon may well be the best route for further research.

\section{Spontaneous ignition}

While the case of the Cioclovina Cave cannot be proven not to have spontaneously ignited, we must be wary of claims of such an event, since spontaneous or natural ignition in a cave environment (other than dry entrances) is probably extremely unlikely.

Moqbel et al. (2010) define ignition as rapid transition from exothermic oxidation to self-supported ignition. Many studies confirm that bacterial decomposition can heat materials only up to $60^{\circ} \mathrm{C}$ or so (e.g., Koivula et al., 2000; Rynk, 2000), and then the heat kills the bacteria. After this, combustion can only happen if exothermic chemical oxidation continues the heating process, to reach the ignition-point temperatures of $150-200^{\circ} \mathrm{C}$ required for smouldering fire. The relatively limited criteria that might allow spontaneous combustion (Rynk, 2000; Hänninen, 2017) include: relatively dry material (critical moisture content: 20$45 \%)$; large piles of material; ambient temperature above critical level (to restrict heat loss); and limited air flow (enough to supply oxygen for microbial action and chemical oxidation, but not enough to dissipate heat - material must be porous enough to allow limited air diffusion throughout).

Although the conditions required to trigger spontaneous ignition are rather stringent, the literature does suggest that it is not uncommon in artificially-created surface piles of organic matter (e.g., hay, dung, wood piles: Li et al., 2006; Hänninen, 2017). However, most of these circumstances are not relevant to cave guano accumulations. The majority of caves have significantly higher humidity than 20$44 \%$. For example, even Cioclovina Cave, although described as a "dry" cave, has a reported relative humidity of $\sim 75-95 \%$ (Onac et al., 2002) or $80-88 \%$ (Dumitrass et al., 2008). Even if microbial action in buried guano raised the temperature to $60^{\circ} \mathrm{C}$ or so, the extremely restricted air flow would not support the required subsequent oxidation (and the images from Cioclovina Cave of the layer that is claimed to have burned - Onac et al., 2007 - show that it is so extremely tightly compacted, buried between layers of clastic sediments, that we cannot envisage any possibility of sufficient air flow or oxygen diffusion to trigger or maintain chemical oxidation).

It is apparent from the literature that spontaneous fires in natural situations are rare, and not extensive. Even in anthropogenically-initiated in-situ peat fires, the burning extends to only $100 \mathrm{~cm}$ depth (Usup et al., 2004), and the huge biomass of worldwide peat deposits across temperate and tropical environments attests to the absence or extreme rarity of spontaneous combustion over 10,000 year timescales. Even in caves that maintain very dry conditions, where decomposition can be essentially arrested for $>10,000$ years, fires are extremely unlikely without human intervention; for example, bat guano from Aden Crater, New Mexico, on which rested a ground sloth dated at 9,840 \pm 160 yr BP (Simons \& Alexander, 1964), retains the original unaltered structure of the fecal pellets.

It is apparent that there are few, if any, unambiguous examples of spontaneous fires in cave guano, especially in moist, buried guano. Most guano fires reported are in very dry caves in hot climates and are more likely to be associated with human activity. We thus argue that it is facile to invoke spontaneous ignition without stringent evidence. It is unfortunate that so many subsequent publications have latched onto the single example, Cioclovina Cave, Romania, where burning of guano may seem like a reasonable explanation for the two high temperature minerals found there. 
For this research we posed the question: how can we recognize that guano has been burned from changes in morphology and or changes in mineralogy? The results of our experimental burning at high temperatures $\left(540^{\circ} \mathrm{C}\right)$ for extended duration (18 hours) show that the colour change is obvious; that, while many features were destroyed, a surprising number of the morphological features survived the treatment; that crystals were severely damaged by rapid dehydration; and that several high temperature minerals were produced, but only one of these, graphite, could be considered as diagnostic of burning.

- Effect on colour and morphology: The most obvious change in morphology at the macro-scale is that the lustrous brown material becomes dull black. The agglutinated fecal pellets lose their coherence. The grain size generally decreases. The grains tend to lose their distinctive morphology. All combustible dry organic matter, such as bat hair or plant matter, is destroyed. At the micro scale, many of the features of individual insect parts are lost by burning. However, a surprising proportion of features survive, although compromised. The setae of insects may be lost or may become shrivelled. The heads and torsos of larger insects can often be recognized, although compromised.

- Effect on crystals and mineralogy: The most obvious change is that burning damages crystals during the process of very rapid dehydration (of gypsum to anyhdrite, and of brushite to whitlockite). Crystals from the fresh guano show clean faces, while the burnt crystals show various states of alteration which opens up cracks and striations, and eventually breaks the larger crystals into smaller fragments. Overall, the burnt material has fewer large crystals. The production of graphite is the only unambiguous indicator of burning. Of the other potential high temperature minerals we created (giniite, bayerite, augelite, tridymite, oldhamite), we show that none is immune from potential synthesis in low temperature conditions by weathering or bacterial action, although, taken as a whole, the suite might be considered as reasonably strong evidence of burning. Future research will be required to assess whether the structure of the carbon in a deposit (specifically the aromaticity and the degree of aromatic condensation) will prove to be an unambiguous test of pyrogenicity.

- Spontaneous ignition: A survey of the conditions required for spontaneous ignition of organic matter suggests that it is extremely unlikely for this to occur in caves, contrary to the literature that continues to assert (usually citing the single case of Cioclovina Cave as definitive evidence) that cave guano regularly erupts into flame, reproducing this false meme like a virus. We conclude that any claim of spontaneous ignition of cave guano must be rigorously supported by plausible evidence.
Thanks to Bogdan P. Onac for advice on crystal morphology, and to Stephen Hillier, James Hutton Institute, for XRD tests. Thanks also to referees for helpful comments.

Authorship statement: Both authors designed the study. DAM did the ignition and XRD tests. JL did the SEM work and most of the analysis and writing.

\section{REFERENCES}

Anthony, J.W., Bideaux, R.A., Bladh, K.W., Nichols, M.C., 2000. Handbook of mineralogy, Volume IV. Arsenates, Phosphates, Vanadates. Mineral Data Publishing, Tucson, AZ, $680 \mathrm{p}$.

Audra, P., De Waele, J., Bentaleb, I., Chroňáková, A., Krištůfek, V., D’Angeli, I.M., Carbone, C., Madonia, G., Vattano, M., Scopelliti, G., Cailhol, D., Vanara, N., Temovski, M., Bigot, J.-Y., Nobécourt, J.-C., Galli, E., Rull, F., Sanz-Arranz, A., 2019. Guanorelated phosphate-rich minerals in European caves. International Journal of Speleology, 48(1), 75-105. https://doi.org/10.5038/1827-806X.48.1.2252

Bard, F., Bilal, E., 2011. Semi-batch precipitation of calcium sulfate dihydrate from calcite and sulfuric acid. Carpathian Journal of Earth and Environmental Sciences, 6(1), 241-250.

Berna, F., Goldberg, P., Horwitz, L.K., Brink, J., Holt, S., Bamford, M., Chazan, M., 2012. Microstratigraphic evidence of in situ fire in the Acheulean strata of Wonder-werk Cave, Northern Cape Province, South Africa. Proceedings of the National Academy of Sciences, 109(20), E1215-E1220. https://doi.org/10.1073/pnas.1117620109

Bird, M., Boobyer, E., Bryant, C., Lewis, H., Paz, V., Stephens, W., 2007. A long record of environmental change from bat guano deposits in Makangit Cave, Palawan, Philippines. Earth and Environmental Science Transactions of the Royal Society of Edinburgh, 98(1), 59-69. https://doi.org/10.1017/S1755691007000059

Brain, C.K., 1967. Procedures and some results in the study of Quaternary cave fillings. In: Bishop, W.W., Clark, J.D. (Eds.), Background to evolution in Africa. University of Chicago Press, Chicago, p. 285-301.

Chakhmouradian, A.R., Reguir, E.P. and Mitchell, R.H., 2002. Strontium-apatite: new occurrences, and the extent of Sr-for-Ca substitution in apatite-group minerals. The Canadian Mineralogist, 40, 121-136. https://doi.org/10.2113/gscanmin.40.1.121

Cressey, G., 2005. Sulphates. In: Selly, R.C., Cocks, R.M., Plimer, I.R (Eds.), Encyclopedia of geology. Academic Press, p. 572-573. https://doi.org/10.1016/B0-12-369396-9/00280-X

Dar, S.A., Khan, K.F., Birch, W.D., 2017. Sedimentary: Phosphates, In: Reference module in Earth Systems and Environmental Sciences. Elsevier. https://doi.org/10.1016/B978-0-12-409548-9.10509-3 De Waele, J., Carbone, C., Sanna, L., Vattano, M., Galli, E., Sauro, F., Forti, P., 2017. Secondary minerals from salt caves in the Atacama Desert (Chile): a hyperarid and hypersaline environment with potential analogies to the Martian subsurface. International Journal of Speleology, 46(1), 51-66. https://doi.org/10.5038/1827-806X.46.1.2094 
Deer, W.A., Howie, R.A., Wise, W.E., 2004. Rock-forming minerals: Framework silicates: Silica minerals, feldspathoids and the zeolites. Geological Society, p. 22.

Dumitraş, D-G, Marincea, Ş. Bilal, E., Hatert, F., 2008. Apatite- $(\mathrm{CaOH})$ in the fossil bat guano deposit from the "dry" Cioclovina Cave, Sureanu Mountains, Romania. The Canadian Mineralogist, 46(2), 431-445. https://doi.org/10.3749/canmin.46.2.431

Flicoteaux, R., Lucas, J., 1984. Weathering of phosphate minerals. In: Nriagu, J.O., Moore, P.B. (Eds.), Phosphate minerals. Springer, Berlin, p. 292-317. https://doi.org/10.1007/978-3-642-61736-2_9

Gázquez, F., Calaforra, J.M., Forti, P., 2011. Black MnFe crusts as markers of abrupt palaeoenvironmental changes in El Soplao Cave (Cantabria, Spain). International Journal of Speleology, 40(2), 163-169. https://doi.org/10.5038/1827-806X.40.2.8

Gonçalves, R., Martins, R., Costa, C.M., Ferdov, S., Lanceros-Méndez, S., 2017. Crystal morphology control of synthetic giniite by alkaline cations and $\mathrm{pH}$ variations. Crystal Growth and Design, 17(9), 47104714. https://doi.org/10.1021/acs.cgd.7b00590

Haberle, C.W., Garvie, L.A., 2017. Extraterrestrial formation of oldhamite and portlandite through thermal metamorphism of calcite in the Sutter's Mill carbonaceous chondrite. American Mineralogist, 102(12), 2415-2421.

https://doi.org/10.2138/am-2017-6180

Hall, L.S., Richards, G., Abdullah, M.T., 2002. Bats of Niah National Park, Sarawak. Sarawak Museum Journal, 52, 255-282.

Halliday, W.R., 1954. Protection against lightning. Journal of the American Medical Association, 155(6), 859. https://doi.org/10.1001/jama.1954.03690270055029

Hänninen, K.I., 2017. A chemical mechanism for selfignition in a peat stack. Environment and Ecology Research 5(1), 6-12.

https://doi.org/10.13189/eer.2017.050102

Hill, C.A., Forti, P., 1997. Cave minerals of the world (2nd ed.). National Speleological Society, Huntsville, Alabama, $463 \mathrm{p}$.

IMA database of Mineral Properties, 2021. https://rruff. info/ima/ [accessed May 2021].

Judai, K., Iguchi, N., Hatakeyama, Y., 2016. Lowtemperature production of genuinely amorphous carbon from highly reactive nanoacetylide precursors. Journal of Chemistry, 2016, 7840687. https://doi.org/10.1155/2016/7840687

Kaal, J., Martinez-Pillado, V., Martínez Cortizas, A., Sanjurjo-Sánchez, J., Aranburu, A., Arsuaga, J.L., Iriarte, E., 2021. Bacteria, guano and soot: Source assessment of organic matter preserved in black laminae in stalagmites from caves of the Sierra de Atapuerca (N Spain). International Journal of Speleology, 50(2), 121135. https://doi.org/10.5038/1827-806X.50.2.2382

Karkanas, P., Rigaud, J.-P., Simek, J.F., Albert, R., Weiner, S., 2002. Ash bones and guano: a study of the minerals and phytoliths in the sediments of Grotte XVI, Dordogne, France. Journal of Archaeological Science, 29, 721-732. htps://doi.org/10.1006/jasc.2001.0742

Kijjanapanich, P., Annachhatre, A.P., Lens, P.N.L., 2014. Biological sulfate reduction for treatment of gypsum contaminated soils, sediments, and solid wastes. Critical Reviews in Environmental Science and Technology, 44(10), 1037-1070.

https://doi.org/10.1080/10643389.2012.743270

Kilic, A.M., Kilic, Ö., 2007. The phase transition in natural gypsum. Asian Journal of Chemistry, 19(4), 3157-3168.
Koivula, N., Hänninen, K., Tolvanen, O., 2000. Windrow composting of source separated kitchen biowastes in Finland. Water Management and Research, 18, 160-173. https://doi.org/10.1177/0734242X0001800208

Leskeviciene, V., Sarlauskaite, I., Nizeviciene, D., Kybartiene, N., 2010. Influence of the gypsum dehydration temperature and alkali additives on the properties of anhydrite cement. Science of Sintering, 42, 233-243. https://doi.org/10.2298/SOS1002233L

Li, X.-R., Koseki, H., Momota, M., 2006. Evaluation of danger from fermentation-induced spontaneous ignition of wood chips. Journal of Hazardous Materials, $135,15-20$.

https://doi.org/10.1016/j.jhazmat.2005.11.034

Long, A., Hansen, R.M., Martin, P.S., 1974. Extinction of the Shasta Ground Sloth. Geological Society of America Bulletin, 85, 1843-1848.

https://doi.org/10.1130/0016-7606(1974)85\%3C184 3:EOTSGS\%3E2.0.CO;2

Ma, X., Liu, Y., Zhu, B., 2018. Synthesis and characterization of pure strontium apatite particles and nanoporous scaffold prepared by dextrose-templated method. Materials Research Express, 5(2), 025002. https://doi.org/10.1088/2053-1591/aaa84c

Malikova, T.V., Golovanova, O.A., Chikanova, E.S., 2018. Physicochemical properties of calcium phosphatechitosan composites and scaffolds. Inorganic Materials, 54(9), 957-964. https://doi.org/10.1134/S0020168518090066

Marincea, S.., Dumitraş, D.-G., 2005. First reported sedimentary occurrence of berlinite $\left(\mathrm{AlPO}_{4}\right)$ in phosphate-bearing sediments from Cioclovina Cave, Romania - Comment. American Mineralogist, 90, 12031208. https://doi.org/10.2138/am.2005.418

Martini, J.E.J., 1994a. The combustion of bat guano a poorly known phenomenon. Bulletin of the South African Speleological Association, 33, 70-72.

Martini, J.E.J., 1994b. Two new minerals originated from bat guano combustion in Arnhem Cave, Namibia. South African Speleological Association Bulletin, 33, 66-69.

Martini, J.E.J., 1997. Pyrocoproite $\left(\mathrm{Mg}(\mathrm{K}, \mathrm{Na})_{2} \mathrm{P}_{2} \mathrm{O}_{7}\right.$, monoclinic), a new mineral from Arnhem Cave (Namibia), derived from bat guano combustion. In Jeannin, P.-Y. (Ed.), Proceedings of the 12th International Congress of Speleology, La Chaux-de-Fonds, Switzerland, Speleo Projects, Basel, 1, 223-225.

Mathur, J., Bizzoco, R.W., Ellis, D.G., Lipson, D.A., Poole, A.W., Levine, R., Kelley, S.T., 2007. Effects of abiotic factors on the phylogenetic diversity of bacterial communities in acidic thermal springs. Applied and Environmental Microbiology, 73(8), 2612-2623. https:/doi.org/10.1128/AEM.02567-06

McFarlane, D.A., Lundberg, J., 2018. New records of guano-associated minerals from caves in northwestern Borneo. International Journal of Speleology, 47(2), 119126. https://doi.org/10.5038/1827-806X.47.2.2169

Mindat, 2021a. Hudson Institute of Mineralogy. https:// www.mindat.org/min-1695.html [accessed Jan 2021]

Mindat, 2021b. Hudson Institute of Mineralogy. https:// www.mindat.org/min-580.html [accessed Jan 2021]

Mindat, 2021c, Hudson Institute of Mineralogy. https:// www.mindat.org/min-4015.html [accessed Jan 2021]

Moqbel, S., Reinhart, D., Chen, R.H., 2010. Factors influencing spontaneous combustion of solid waste. Waste Management, 30(8-9), 1600-1607. https://doi.org/10.1016/j.wasman.2010.01.006

Nedkov, I., Groudeva, V., Angelova, R., Iliev, M., Slavov, L., 2016. New iron oxides/hydroxides biomaterials for application in electronics and medicine. Machines. Technologies. Materials., 10(12), 48-51. 
Nriagu, J.O., 1976. Phosphate-clay mineral relations in soils and sediments. Canadian Journal of Earth Sciences, 13, 717-736. https:/doi.org/10.1139/e76-077

Oakley, K.P., 1954. Evidence of fire in South African cave deposits. Nature, 174, 261-262. https://doi.org/10.1038/174261b0

Onac, B.P., Effenberger, H.S., 2007. Re-examination of berlinite $\left(\mathrm{AlPO}_{4}\right)$ from the Cioclovina Cave, Romania. American Mineralogist, 92(11-12), 1998-2001. https://doi.org/10.2138/am.2007.2581

Onac, B.P., Forti, P., 2011. Minerogenetic mechanisms occurring in the cave environment: an overview. International Journal of Speleology, 40(2), 79-98. https://doi.org/10.5038/1827-806X.40.2.1

Onac, B.P., White, W.B., 2003. First reported sedimentary occurrence of berlinite $\left(\mathrm{AlPO}_{4}\right)$ in the phosphatebearing sediments from Cioclovina Cave, Romania. American Mineralogist, 88, 1395-1397.

https://doi.org/10.2138/am-2003-8-925

Onac, B.P., Breban, R., Kearns, J., Tămaş, T, 2002. Unusual minerals related to phosphate deposits in Cioclovina Cave, Sureanu Mts. (Romania). Theoretical and Applied Karstology, 15, 27-34.

Onac, B.P., Effenberger, H., Ettinger, K, Cinta Pinzaru, S., 2006. Hydroxylellestadite from Cioclovina Cave (Romania): Microanalytical, structural, and vibrational spectroscopy data. American Mineralogist, 91, 19271931. https://doi.org/10.2138/am.2006.2143

Onac, B.P., Effenberger, H.S., Breban, R.C., 2007. Hightemperature and "exotic" minerals from the Cioclovina Cave, Romania: a review. Studia UBB, Geologia, 52, 3-10. https:/doi.org/10.5038/1937-8602.52.2.1

Parr, J.F., 2006. Effect of fire on phytolith coloration. Geoarchaeology, 21, 171-185. https://doi.org/10.1002/gea.20102

Popova, A.N., 2017. Crystallographic analysis of graphite by X-Ray diffraction. Coke Chemistry, 60, 361-365. https://doi.org/10.3103/S1068364X17090058

Prado-Herrero, P., Garcia-Guinea, J., Crespo-Feo, E., Correcher, V., 2010. Temperature-induced transformation of metavariscite to berlinite. Phase Transitions, 83(6), 440-449.

https://doi.org/10.1080/01411594.2010.490904

Queffelec, A., Bertran, P.I., Bos, T., Lemé, L., 2018. Mineralogical and organic study of bat and chough guano: implications for guano identification in ancient context. Journal of Cave and Karst Studies, 80(2), 1-17. https://doi.org/10.4311/2017ES0102

Rahman, F., 2013. Calcium sulfate precipitation studies with scale inhibitors for reverse osmosis desalination. Desalination, 319, 79-84.

https://doi.org/10.1016/j.desal.2013.03.027

Rakovan, J., Hughes, J., 2000. Strontium in the apatite structure: Strontian fluorapatite and belovite-(Ce). The Canadian Mineralogist, 38, 839-845. https://doi.org/10.2113/gscanmin.38.4.839

Rodriguez-Cintas, A., Cabanes, D., 2017. Phytolith and FTIR studies applied to combustion structures: The case of the Middle Paleolithic site of El Salt (Alcoy, Alicante). Quaternary International, 431(A), 16-26. https://doi.org/10.1016/j.quaint.2015.09.043

Roebroeks, W., 2006. The human colonisation of Europe: where are we? Journal of Quaternary Science, 21, 425435. https://doi.org/10.1002/jqs. 1044

Roebroeks, W., Villa, P., 2011. On the earliest evidence for habitual use of fire in Europe. Proceedings of the National Academy of Sciences, 108(13), 5209-5214. https://doi.org/10.1073/pnas.1018116108
Rynk, R., 2000. Fires at composting facilities: causes and conditions. BioCycle, 41, 54-58.

San Antonio News, 2019. https://spectrumlocalnews. $\mathrm{com} / \mathrm{tx} / \mathrm{san}$-antonio/news/2019/12/18/from-guanoto-gold--the-story-of-the-lost-community-of-blowout-texas [accessed 20 Jan 2021]

Sauro, F., De Waele, J., Onac, B.P., Galli, E., Dublyansky, Y., Baldoni, E., Sanna, L., 2014. Hypogenic speleogenesis in quartzite: the case of Corona 'e Sa Craba Cave (SW Sardinia, Italy). Geomorphology, 211, 77-88.

https://doi.org/10.1016/j.geomorph.2013.12.031

Scheinost, A.C., 2005. Metal oxides. In: Hillel, D. (Ed.), Encyclopedia of soils in the environment. Academic Press, p. 428-438.

https://doi.org/10.1016/B0-12-348530-4/00194-6

Schmidt, G.D., Duszynski, D.W., Martin, P.S., 1992. Parasites of the extinct Shasta Ground Sloth, Nothrotheriops shastensis, in Rampart Cave, Arizona. Journal of Parasitology, 78(5), 811-816.

https://doi.org/10.2307/3283310

Sebela, S., Miler, M., Skobe, S., Torkar, S., Zupancic, N., 2015. Characterization of black deposits in karst caves, examples from Slovenia. Facies, 61(6), 1-13. https://doi.org/10.1007/s10347-015-0430-Z

Shahack-Gross, R., Berna, F., Karkanas, P., Weiner, S., 2004. Bat guano and preservation of archaeological remains in cave sites. Journal of Archaeological Science, 31(9), 1259-1272.

https://doi.org/10.1016/j.jas.2004.02.004

Simoneit, B.R.T., Oros, D.R., Elias, V.O., 2000. Molecular tracers for smoke from charring/burning of chitin biopolymer. Chemosphere - Global Change Science, 2(1), 101-105. https://doi.org/10.1016/S1465-9972(99)00049-5

Simons, E., Alexander, H., 1964. Age of the Shasta Ground Sloth from Aden Crater, New Mexico. American Antiquity, 29(3), 390-391.

https://doi.org/10.2307/277883

Soficaru, A., Petrea, C., Dobos, A., Trinkaus, E., 2007. The human cranium from the Pesstera Cioclovina Uscată, Romania: context, age, taphonomy, morphology, and paleopathology. Current Anthropology, 48, 611-619. https://doi.org/10.1086/519915

Stanienda-Pilecki, K.J.,2018. Magnesium calcite in Muschelkalk limestones of the Polish part of the Germanic Basin. Carbonates and Evaporites, 33, 801821. https://doi.org/10.1007/s13146-018-0437-y

Sudbury, J.B., 2010. Quantitative phytolith analysis: the key to understanding buried soils and to reconstructing paleoenvironments. $\mathrm{PhD}$ Thesis, Oklahoma State University, $421 \mathrm{p}$. https://shareok.org/handle/11244/7750

Suryawanshi, V.B., Chaudhari, R.T., 2014. Growth and characterization of agar gel grown Brushite crystals. Indian Journal of Materials Science, 2014, 189839. https://doi.org/10.1155/2014/189839

Tămaş, T. Miheț, O, Giurgiu, A., 2014. Mineralogy of bat guano deposits from Huda lui Papară Cave (Trascău Mountains, Romania). Carpathian Journal of Earth and Environmental Sciences, 9(3), 25-32.

Toshima, T., Hamai, R., Tafu, M., Takemura,Y., Fujita, S., Chohji, T., Tanda, S., Lie,S., Qin, G.W., 2014. Morphology control of brushite prepared by aqueous solution synthesis. Journal of Asian Ceramic Societies, 2(1), 52-56. https://doi.org/10.1016/j.jascer.2014.01.004

Urbani, F., 1996. Venezuelan cave minerals, a review. Boletín de la Sociedad Venezolana de Espeleologia, 30, 1-13. 
Usup, A., Hashimoto, Y., Takahashi, H., Hayasaka, H., 2004. Combustion and thermal characteristics of peat fire in tropical peatland in Central Kalimantan, Indonesia. Tropics, 14(1), 1-19.

https://doi.org/10.3759/tropics.14.1

Wiedemeier, D.B., Abiven, S., Hockaday, W.C, Keiluweit, M., Kleber, M., Masiello, C.A., McBeath, A.V., Nico, P.S., Pyle, L.A., Schneider, M.P.W., Smernik, R.J., Wiesenberg, G.L.B., Schmidt, M.W.I., 2015. Aromaticity and degree of aromatic condensation of char. Organic Geochemistry, 78, 135-143.

https://doi.org/10.1016/j.orggeochem.2014.10.002

Wolf, M., Lehndorff, E., Wiesenberg, G.L.B., Stockhausen, M., Schwark, L., Amelung, W., 2013. Towards reconstruction of past fire regimes from geochemical analysis of charcoal, Organic Geochemistry, 55, 11-21. https://doi.org/10.1016/j.orggeochem.2012.11.002
Wurster, C.M., Munksgaard, N.C., Zwart, C., Bird, M.I., 2015. The biogeochemistry of insectivorous cave guano: a case study from insular Southeast Asia. Biogeochemistry, 124, 163-175.

https://doi.org/10.1007/s10533-015-0089-0

Yang, S., Hao, Q., Wang, H., 2020. A review of carbon isotopes of phytoliths: implications for phytolithoccluded carbon sources. Journal of Soils and Sediments, 20, 1811-1823.

https://doi.org/10.1007/s11368-019-02548-4 